\title{
The Kurpie region. Transformation of settlement landscape until Poland's accession to the European Union ${ }^{1}$
}

\author{
Agnieszka Starzyk
}

\begin{abstract}
The Kurpie region is among the most interesting ethnographic regions of Poland, with the center of the original, well-preserved and carefully cultivated folk culture of the Kurpie [ethnographic group of the Polish population]. The image of the Kurpie village resulted from centuries of human activity. Over the centuries, transformations of the landscape occurred. Activities that gave the area a modern appearance were based on adaptation of the natural environment for cultivation of land and gradual establishment of human settlements. The traditional folk culture developed by the Kurpie ethnographic group, as well as high value of the natural environment prompted research in the scope of transformation to open settlement landscape of the Kurpie region. The present study was aimed at investigating processes that determined the transformation to the natural and cultural landscape of the Kurpie region.

The territorial scope of the present work covers the Kurpie region located between the Omulew and the Szkwa rivers. In the $15^{\text {th }}$ century, the region was included in the Ostrołeka County and has remained there since then. The time scope of the study concerns the period from when first mention of the area being settled was made to the moment of Poland's accession to the European Union.

The following research methods were adopted for the study: analysis of source literature and literature on the subject undertaken in the present work, historical analysis to cover the development of settlement in the studied area, comparative cartographic analysis in the field of settlement and landscape transformation, statistical analysis in the field of social and technical infrastructure. In the study, landscape and urban-rural inventory was also applied.

The study structure covers issues related to formation and development of settlement in the Kurpie region: 1) the Kurpie region in scientific research, 2) the Kurpie region in folk culture, 3) the Kurpie region - an outline of settlement-agricultural functions, as well as landscape layout, 4) the Kurpie region - characteristics of the settlement landscape, 5) the Kurpie region - dominant changes to the landscape under the influence of socio-economic factors in the period of the 45 post-war years, 6 ) the Kurpie region - dominant modification to the landscape as influenced by socio-economic factors during the political system transformation in Poland.
\end{abstract}

Key words: the Kurpie region, architecture, settlement landscape, natural landscape, cultural landscape

\footnotetext{
${ }^{1}$ The present article was written on the basis of the research presented in the author's doctoral dissertation entitled Przekształcenia otwartego krajobrazu osadniczego na Kurpiowszczyźnie na przykładzie wybranych gmin [Transformations to the open settlement landscape in the Kurpie region, on the example of selected communes].
} 


\section{Introduction}

The image of the Kurpie region countryside resulted from centuries of human activity. Over the centuries, transformations to the landscape were made, based on the adaptation of the natural environment to the needs related to land cultivation and gradual establishment of human settlements. Owing to these amendments, a modern image of the area emerged. The Kurpie area stands as one of the most interesting ethnographic regions, with the center of original, well-preserved and carefully cultivated folk culture of the Kurpie ethnographic group. The Kurpie folk art found a particularly characteristic expression in construction, ornamentation and weaving. The region is famous for its folk art, local customs, folk songs and dances, and its original dialect.

The subject outline of the present study covers the processes of shaping the settlement agricultural and landscape functions, which exerted a significant impact on spatial structure of rural settlement in the Kurpie region. The settlement process in the forests was initiated by miners, tar makers and beekeepers, whose nomadic lifestyle changed over time. In addition to performing the above-mentioned works, they also became farmers, cleared the forest in order to establish villages and their farms [Piaścik 1939]. The territorial scope of the present study covers the area of the Kurpie region, located between the Omulew and Szkwa rivers. In the $15^{\text {th }}$ century, the area was included as part of the Ostrołeka County and has since retained this administrative classification. The Kurpie people inhabit areas that have never constituted a separate administrative unit. In the past, the territory was included in different counties: Ostrołęka, Łomża, Kolna and Przasnyski, then it was attached to two provinces - Ostrołeka and Łomża. However, the largest part of the area has always been incorporated in the Ostrołeka province [Niedziałkowska 1988]. In the $16^{\text {th }}$ and $17^{\text {th }}$ centuries, the forests of northern Mazovia were known as Puszcza-Zagajnica [Zagajnica Forest], with specific names derived from the name of the starosty they were located in, e.g. Puszcza-Zagajnica Łomżyńska [Łomża Zagajnica Forest], Puszcza-Zagajnica Nowogrodzka [Nowogród Zagajnica Forest], or Puszcza-Zagajnica Ostrołęcka [Ostrołęka Zagajnica Forest], also called Puszcza Skwańska [Szkwańska Forest], situated between the Omulew and the Skwa (Szkwa) rivers, which are tributaries of the Narew river. Coniferous forests stretching here, later called Puszcza Zielona [Zielona Forest], now also known as Puszcza Myszyniecka [Myszeniecka Forest], were initially owned by Mazovian princes and then by Polish kings.Together with Puszcza Biała [Biała Forest], adjacent to it from the west and south-west, Puszcza Zielona [Zielona Forest] acquired the common name of Puszcza Kurpiowska [Kurpie Forest] (of the Kurpie region) at the beginning of the $18^{\text {th }}$ century. Currently, this name covers only the area of Puszcza Zielona [Zielona Forest], recognized as Kurpie region proper [Niedziałkowska 1988].

At the beginning of the 1920s, regional distinctiveness of the Kurpie area led deputies of the Łomża region, most importantly Adam Chętnik (deputy between 1922-1927), to put forward a project of separating the Kurpie region into Starostwo Kuropiowskie [Kurpie Starosty] at the parliamentary forum. However, the project failed to gain approval, which meant that the region administratively remained divided between several counties. 
On January $1^{\text {st }}, 1999$, following an administrative reform, the Kurpie region was included in three voivodeships: Mazowieckie [Mazovian Voivodeship], Podlaskie [Podlaskie Voivodeship] and, a small part of Kurpie, in Warmińsko-Mazurskie [Warmian-Mazurian Voivodeship $]^{2}$.

The research covers the Kurpie communes located in the Mazowieckie [Mazovian Voivodeship], in the Ostrołeka poviat, with the exception of Ostrołeka - a town with poviat rights. The research concerns the following communes: Baranowo, Czarnia, Kadzidło, Lelis, Łyse, Myszyniec and Olszewo-Borki. Myszyniec is an urban-rural commune, whereas the remaining communes are of rural nature.

\section{Research methodology}

The following research methods were adopted:

- source literature analysis and analysis of literature on the subject of the present work,

- historical analysis that covers development of settlement in the studied area,

- comparative cartographic analysis in the field of settlement and landscape transformation,

- statistical analysis of social and technical infrastructure.

Moreover, landscape and urban-rural inventory was used for the study.

\section{The Kurpie region in scientific research}

Puszcza Zielona [Zielona Forest] in the Kurpie region, despite being a relatively young area in ethnographic terms, proves to be one of the best explored ones in Poland. Extensive amount of comprehensive literature was published on the topic, as the Forest has long attracted the attention of numerous researchers and writers.

The isolation of the region was its characteristic feature, as for many centuries up until 1945, these areas were situated on the borders of Poland and constituted borderlands of a sort [Pajka 1996]. No large estates, such as ordinances, or medium estates and manors with court services were present in the area, therefore serfdom was unknown here. The inhabitants of these lands, called Kurpie (the name was derived from footwear made of linden wood), lived poorly, but as free people.

\footnotetext{
2 The reform of public administration is an important condition for social and economic changes in Poland. The country's administrative system, in force until December 31 ${ }^{\text {st }}, 1998$, was not only centralized, but also based on the domination of the sectoral-departmental system over the territorial system.

The two-tier administrative division (commune and voivodeship) made it impossible to depart from the departmental, centralist model of administration. The new division resulted in the transfer of many tasks and competences from the center to voivodeships. At the same time, the territorial system was reorganized by creating large voivodeships, i.e., local government units capable of conducting regional policy and performing supra-local tasks, but not nationwide ones. These tasks do not cover the entire country.
} 
The source literature on this region includes plentiful scientific publications that discuss various aspects of the Kurpie region. Due to the thematic scope of the present study, the research on source literature has been limited to works that present issues related to the essence of the research in a synthetic way.

The first descriptions of the land and culture of the Kurpie group appear at the turn of the $16^{\text {th }}$ and $17^{\text {th }}$ century. These outlines were included in the first codifications of laws, written by Krzysztof Niszczycki (1540-1617) and Stanisław Skrodzki, reports by missionaries, e.g., priest Łukasz Kościesza-Załuski (1604-1675), numerous descriptions and reports by historians, including Jędrzej Święcicki ( $16^{\text {th }} / 17^{\text {th }}$ century) or Marcin Kromer, as well as in mentions by foreigners.

The $19^{\text {th }}$ century brought substantial amounts of literature by researchers of Poland's past. In their works, some authors made attempts to analyze the distinctive culture and way of life of the Kurpie people. It is worth mentioning names such as Wincenty Hipolit Gawarecki (1788-1852), Wincenty Pol (1807-1872), and Kazimierz Władysław Wójcicki (1807-1879) here.

Successive generations of researchers of the Kurpie area described the region in a more and more accurate and systematic way. Increasingly detailed descriptions were published by Wiktor Czajewski (under the pseudonym of Antoni Chleboradzki, 1857-1922), Adam Zakrzewski (under the pseudonym of Tomek Piast, 1856-1912), Ludwik Krzywicki (18591941), Zygmunt Gloger (1845-1910), Karol Potkański (1861-1907) or Stanisław Chełchowski [Mikulska 1998].

In the first half of the $20^{\text {th }}$ century, first attempts to publish monographic studies concerning individual aspects of the Kurpie culture were made. In this period, among the leading researchers who dealt with this region the following names should be mentioned: Franciszek Piaścik (1902-2000), Adam Chętnik (1885-1967), as well as priest Władysław Skierkowski, a researcher and documentalist of the Kurpie folklore (1886-1941).

The direction of research suggested in the works by Ludwik Krzywicki and Karol Potkański was undertaken by no researchers until Franciszek Piaścik. In the years 19281930, he conducted studies in the field of architecture and settlement in the Kurpie region. The collected materials and archival sources, no longer available following the outbreak of World War II, provided the basis for his writing the book Osadnictwo w Puszczy Kurpiowskiej [Settlement in the Kurpie Forest], which appeared in print in 1939. It was the first scientific work in which layouts of Kurpie villages were thoroughly analyzed in order to recreate the process of their formation. In his dissertation, Franciszek Piaścik managed to prove that in order to conduct an in-depth analysis of the settlement process, it is necessary that scientists in the field of architecture and urban planning participate in research.

In the first decades of the $20^{\text {th }}$ century, Adam Chetnik conducted elaborate studies on the Kurpie region. The research focused mainly on the history and culture of the Kurpie region, and was characterized by a considerable range of scientific interests in regional issues voiced by the researcher. In his works, Chętnik conveyed detailed description of issues related to the geographical environment, natural resources, history and various areas of regional culture. 
In the years 1955-1970, the Kurpie region was covered by systematic scientific research. The Department of Ethnography of the Institute of the History of Material Culture, The Polish Academy of Sciences and the Department of Ethnography, the University of Warsaw organized the "Ekspedycja Kurpiowska [The Kurpie Expedition]" under the direction of Anna Kutrzeba-Pojnarowska. As a result of this research, a 3-volume monograph entitled Kurpie - Puszcza Zielona [Kurpie-Zielona Forest] emerged. The discussed work provides an advanced attempt to analyze the complex structure of the region in order to arrive at an integral outlook on cultural processes that occurred in the Kurpie region.

In 1986, Ostrołęckie Towarzystwo Naukowe (OTN) [The Ostrołęka Scientific Society] was established. In October 1992, the OTN assumed the name after Adam Chętnik, an outstanding regionalist. The basic tasks of OTN include scientific research and popularization of scientific knowledge concerning the region. In 1987, "Zeszyt Naukowy" magazine was published for the first time, and to this day it is systematically published as an almanac. This periodical, very important to the region, plays an important scientific and cultural role. In addition to activities of a strictly scientific nature, the OTN implements popularization projects that activate the inhabitants, as well as supporters of the Kurpie region.

The beginning of the 1990s saw a breakthrough in terms of development of regional organizations and increased interest of inhabitants of various parts of Poland in their "little homelands". After years of being silent, local communities began to rebuild symbols of their own identity. In the Kurpie region, a revival of thinking about the area's history and culture was noticeable. Initially, participants of regional movement, based on local ties, comprised a group of intelligentsia emotionally connected with the Kurpie region. Over time, the rural population joined in the promotion of their native culture as well.

Despite its relatively short history, the Kurpie region boasts extensive subject literature, with particular emphasis to its history and folk culture. To a lesser extent, the studies concern settlement processes, especially those that occurred during the transformation period from 1989 to 2004, that is to Poland's accession to the European Union.

\section{The Kurpie region in folk culture}

The oldest traces of human existence in the Kurpie region date back to the Stone Age, namely the turn of the Mesolithic and Neolithic periods (approx. 4000-1700 years BCE) and are related to Pit-and-Comb Pottery culture. In the Bronze Age, numerous settlements in the area of today's Puszcza Zielona [Zielona Forest] were associated with the occurrence of bronze, which served as the main raw material for the production of ornaments and weapons, and then tools at that time. In that period, the economy of the area was based on hunting, gathering, fishing and seasonal forest farming. The life of the settlers underwent rather slow transformations, as compared to the previous epoch. This is evidenced by the pottery produced by them, the way stone was processed, or the funeral rites they would practice. 
Over time, the funeral rituals were changed into cremated skeleton burials. At the turn of the $8^{\text {th }}$ and $7^{\text {th }}$ century BCE, a collapse of dynamic settlement process observed so far was experienced. This was probably due to the climate cooling, as well as the rise in water levels. Settlement was focused mainly in the vicinity of watercourses, but not in their immediate vicinity and upon hills. This process was intensified until settlement emptiness in the area of Puszcza Zielona [Zielona Forest] was observed, which lasted from the turn of the $4^{\text {th }}$ and $5^{\text {th }}$ centuries AD., up to the $13^{\text {th }}$ century. It was then that re-settlement in the study area dates back to. Prehistoric settlement in the area is documented by numerous archaeological sites.

Regardless of the region to which it is assigned, folk culture is characterized by universal content, which includes such elements as the fundamental importance of family, family character, respect for land, the surrounding nature, recognition of work and dignity thereof, maintaining the patrimony as an effective form of economic organization, guarantying the rights of the individual, family and democratization in society, recognition of local and regional community, as well as natural-agrarian and religious-worldview criteria for the valorization of what is known as ethical invariants [Jaworowski and Jankowski 1996]. In the Kurpie region, as well as in Poland as a whole, a renaissance of folk culture has been observed since the beginning of the 1990s. This includes the return of certain elements of traditional Kurpie culture. A strong internal integration of the society, based on a sense of separateness and a sense of self-worth may be seen as an indispensable factor in creating this culture. To quote B. Jałowiecki, "the contemporary cultural region is a spatial system for satisfying human needs, it is the common present of the past items that make up the common present of the future items". [Author's own trans.; Jałowiecki 1989].

The adopted scope of the present work restricts research on construction to rural areas that create various spatial systems. The folk art of the Kurpie people found its expression primarily in wooden folk architecture. The abundance of good quality wood and mastery of carpentry made it possible to erect magnificent houses. The beginnings of Kurpie culture date back to the $15^{\text {th }}$ century, but its greatest flourishing period was noted towards the end of the $19^{\text {th }}$ century and the early $20^{\text {th }}$ century. The architectural ethnographic monuments that have survived to this day date back to this period as well.

The traditional architecture forms of the Kurpie region are inseparably linked with nature that boasts the open landscape of the Kurpie region. These forms serve as symbol of cultural distinctiveness of the region and its local identity. The natural isolation of the studied area, the conservatism of rural communities, and thus their lesser susceptibility to changes, led to the preservation of traditional building methods and to traditional use of buildings. Building a house was a ritual. During the construction of the cottage, the owner organized "zakładziny" [commencement of the construction], to which he invited foremen with workers and neighbors. On hewn logs and beams, refreshments with beer were provided. Once the building was finished by carpenters, "wianek" [wreath-hanging] was arranged - a bunch of green branches were hooked on the top. Once the house was completed, it was consecrated by a local priest. After the blessing, usually a feast and dances on the new floor were organized [Chętnik 1913]. 
Chałupa Kurpiowska [The Kurpie Cottage] and farm buildings dating back to before World War II and preserved to this day, were entered under protection as cultural heritage objects of conservation interest in the 1990s. Until today, mainly wooden houses and, less commonly, wooden farm buildings, such as pigsties, barns, coach houses, woodsheds, and granaries, have survived. Among the preserved wooden buildings, cottages from the interwar period are most numerous. Buildings erected at the turn the $19^{\text {th }}$ and $20^{\text {th }}$ century can also be found, but their condition should be described as poor. Despite the fact that these buildings are recognized as valuable in studies at municipal level and thus should be protected, their condition is terrible, it is frequently even impossible to describe their original layout.

The heritage inherent in the regional architecture is inextricably linked with the local community customs, the broadly understood philosophy of life and respect for the surrounding landscape. The so-called objects of small architecture play a vital role in the cultural landscape of the Kurpie area. Wayside shrines and crosses, fences and fencing, or wells are works of folk crafts, often of great artistic value. As such, these objects should be protected being symbols of the cultural distinctiveness of the Kurpie region.

The economy and the resulting economic conditions exerted a significant impact on the development of the Kurpie culture. Owing to the poor quality of soils and simple tools, agriculture could not support the large Kurpie family fully. Therefore, it was necessary to look for sources of additional income. Numerous crafts and folk crafts, such as woodwork, carpentry, plaiting, weaving, and amber-making developed as a result. Due to the natural isolation of the region and its poverty, craft activities and additional production were based on raw materials obtained from the farm itself or gathered in the forest. The need to minimize expenses resulted in creating handmade items necessary on the farm.

The fascinating Kurpie folklore, namely its customs, songs, dances, fairy tales, traditions and legends were associated with the forest and the activities of the Kurpie people. Today, in addition to plentiful publications of high value, this folklore may be encountered during annual events and regional shows organized in Puszcza Zielona [Zielona Forest].

The folk culture of the Kurpie region derives from the life of its inhabitants, the surrounding nature and the availability of raw materials. Tradition was passed down from generation to generation. Longstanding attachment of the Kurpie people to their land and its culture makes it possible to see the culture of the region as a living, continued and developed phenomenon. In particular, it can be observed in the vicinity of Kadzidło, where various, largely unaltered, material and non-material elements of the old forest-based culture have been preserved in the village itself and in the surrounding areas. This situation was caused by a number of factors, including the central location of Kadzidło in the region, and thus less susceptibility to the influence of non-regional cultural patterns than it was the case on the outskirts (Figs. 1-7). ${ }^{3}$

\footnotetext{
${ }^{3}$ Agnieszka Starzyk is the author of all the photographs in the article (Figs. 1-7).
} 

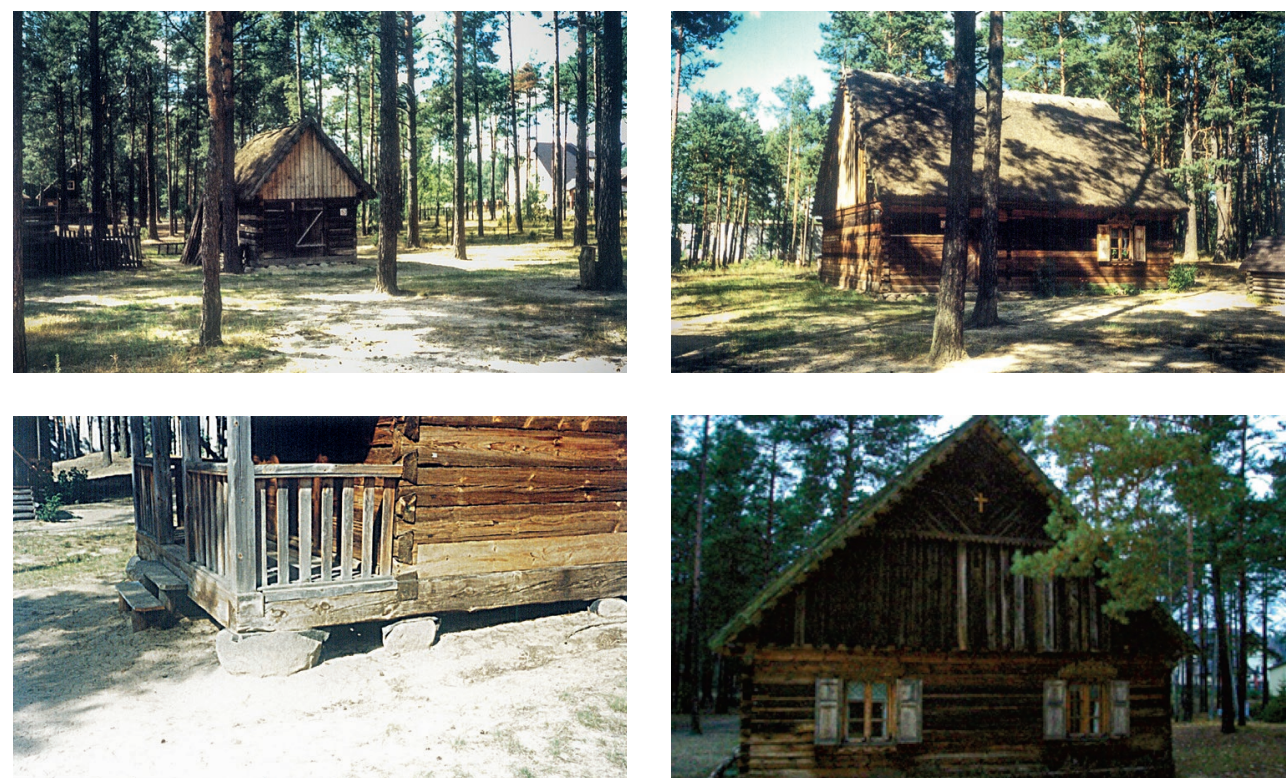

Fig. 1. The Kurpie Open-Air Museum in Kadzidło - buildings
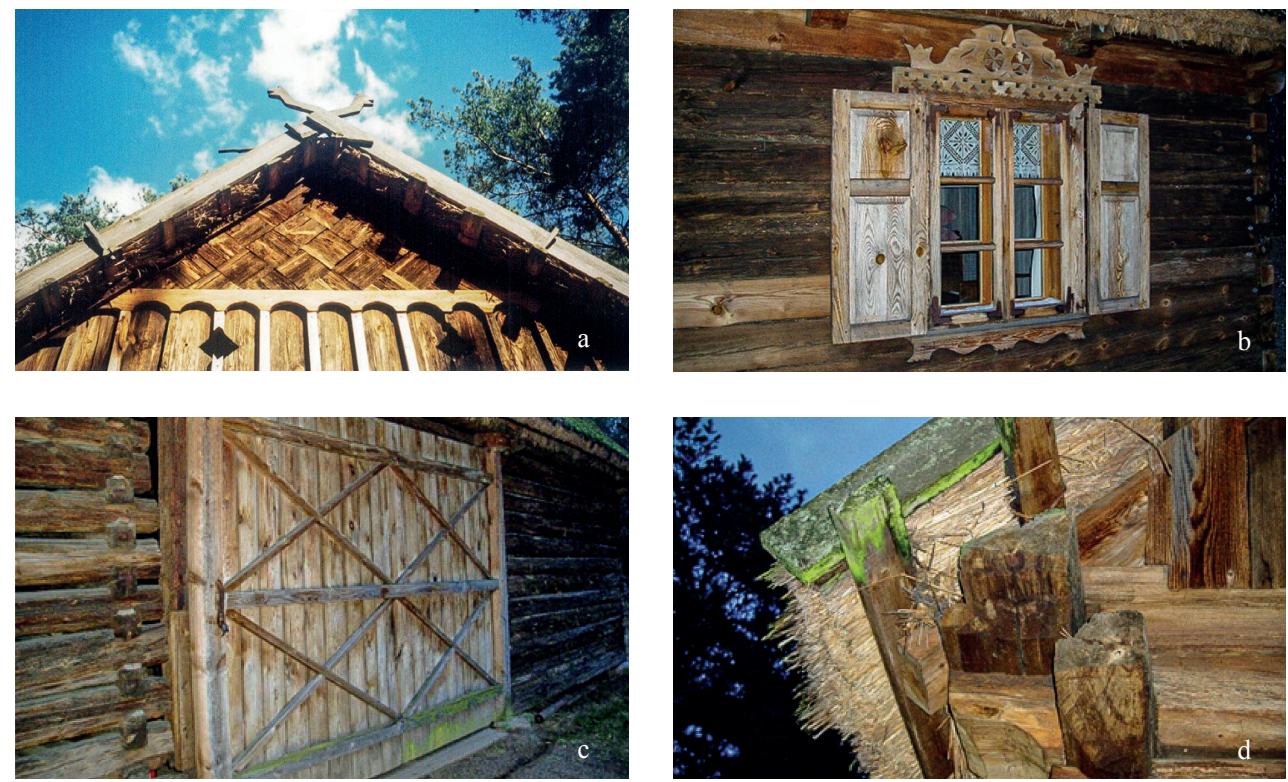

Fig. 2. The Kurpie Open-Air Museum in Kadzidło: a) śparogi (decorative finial placed on top of the roof), b) shutters, c) door, d) roof 

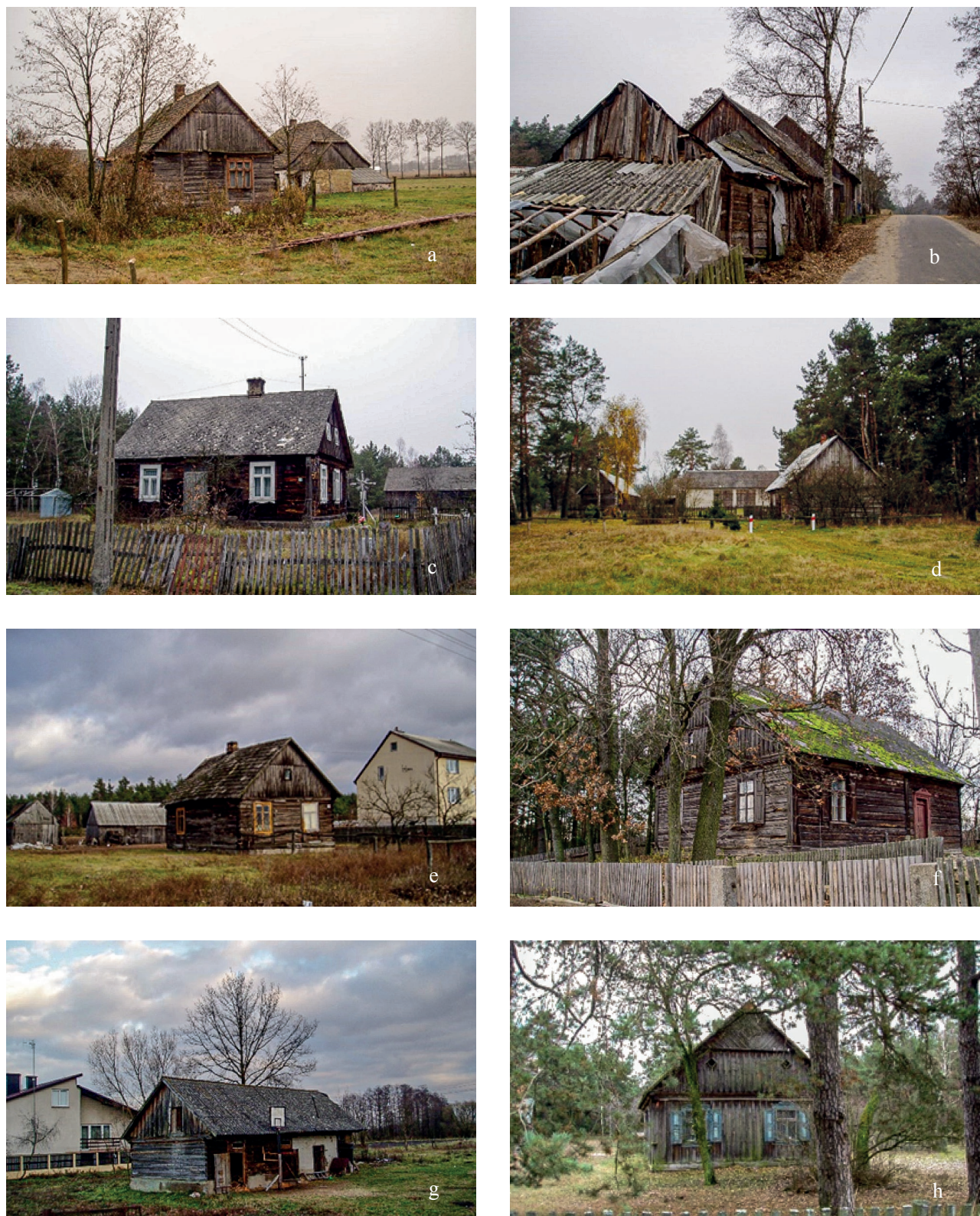

Fig. 3. Examples of preserved wooden buildings in the Kurpie landscape: a) Grabowo - a cottage from the beginning of the $20^{\text {th }}$ century, b) Grabowo - farm buildings from the XIX/XX century,

c) Olszewka - a cottage from the end of the $19^{\text {th }}$ century, d) Olszewka - a homestead from the end of the $19^{\text {th }}$ century, e) Łęg Starościński - a cottage from 1931,f) Kierzek - cottage from ca. 1920, g) Brodowe Łąki - cottage ruin from the second half of the $19^{\text {th }}$ century, h) Gleba - cottages from the beginning of the $20^{\text {th }}$ century 

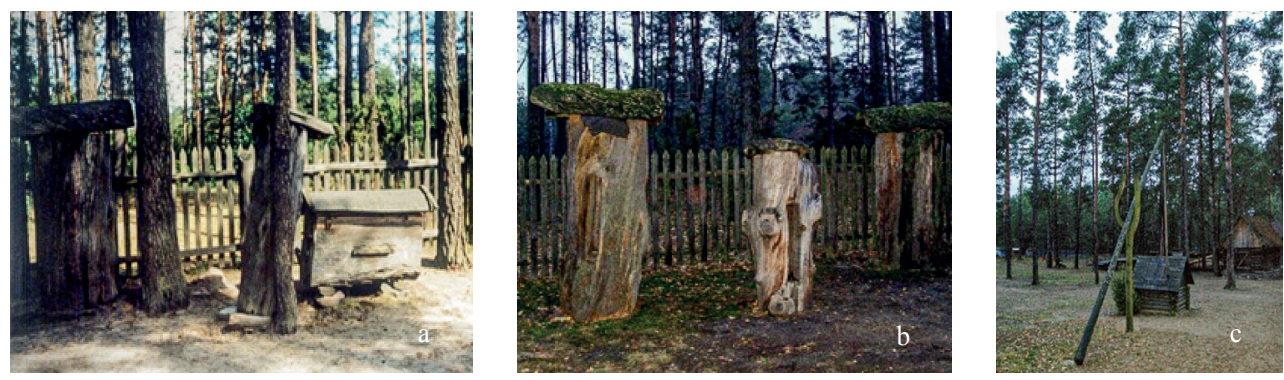

Fig. 4. The Kurpie Open-Air Museum in Kadzidło: a) and b) apiaries, c) well
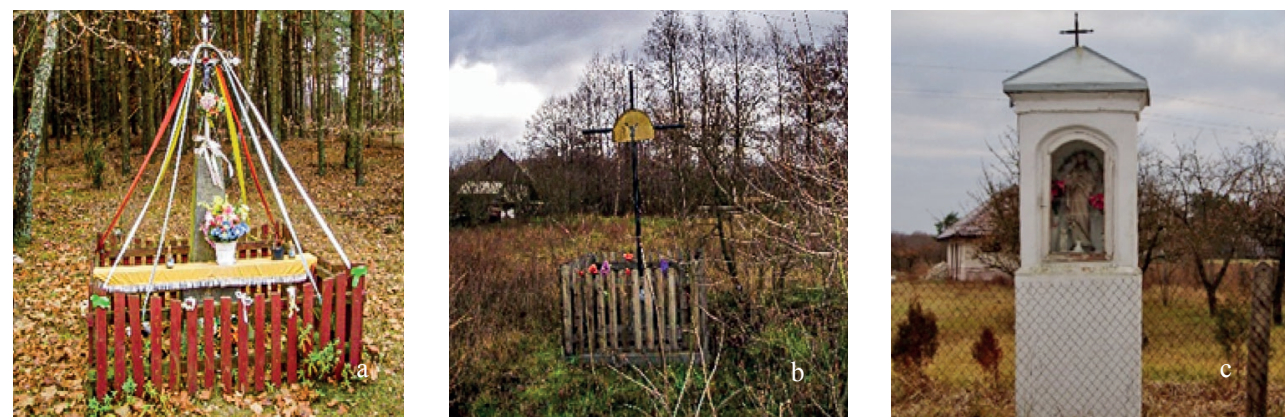

Fig. 5. a) and b) Roadside crosses characteristic of the Kurpie landscape, c) Chudek - brick chapel from the beginning of the $20^{\text {th }}$ century
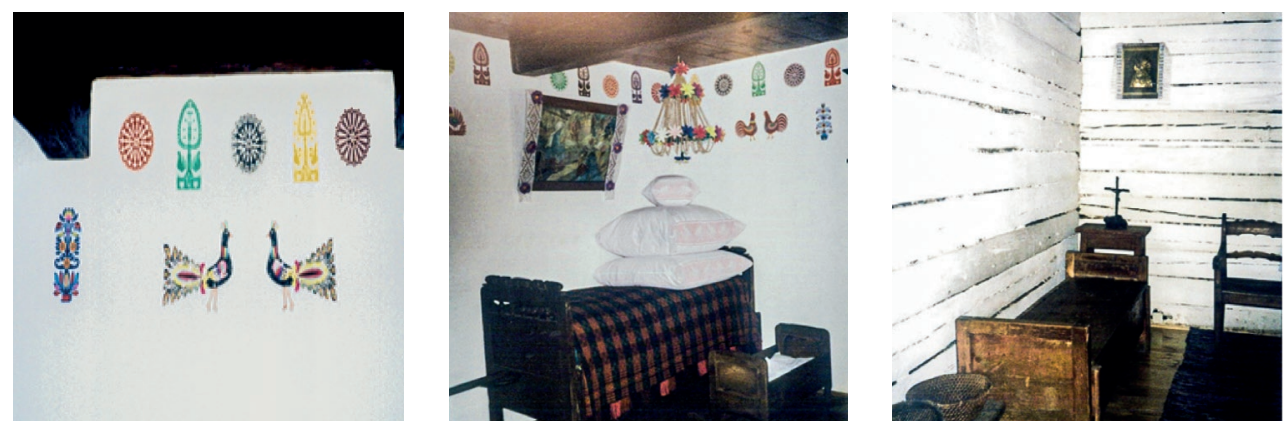

Fig. 6. The Kurpie Open-Air Museum in Kadzidło: interiors of the chambers
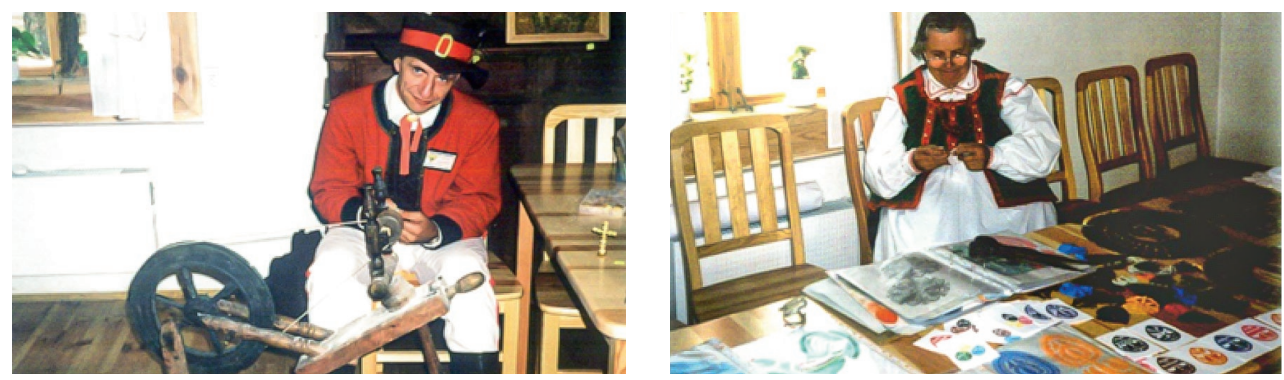

Fig. 7. Additional income-generating activities of the Kurpie region presented at the Kurpie Open-Air Museum in Kadzidło 


\section{The Kurpie region - outline of shaping settlement-agricultural functions and landscape}

Towards the end of the $14^{\text {th }}$ century, the lands surrounded by forests began to be populated, which created a contrast between the forest and its surroundings [Piaścik 1939]. As written by Ludwik Krzywicki, an outstanding researcher on settlement in the area of Puszcza Zielona [Zielona Forest] in his dissertation entitled "Kurpie" (1982): "The dates when neighboring towns: Kolna (1435), Nowogród (1428), Ostrołęka (1373), Chorzela (1542) emerged may be seen as signposts of cultural work that slowly surrounded Puszcza Szkwańska [Szkwańska Forest] with arable fields." [Author's own trans.]

In the $15^{\text {th }}$ century, the lands on the central Vistula River, the lower Bug River and the Narew River, thus the Kurpie region as well, rested with the Dukes of Mazovia. The areas of Puszcza Zielona [Zielona Forest] belonged to the part of Mazovia incorporated in 1526, and by virtue of Truce of Yam-Zapolsky in 1582, which determined the borders of the Polish-Lithuanian Commonwealth, it was included in the Crown of the Kingdom of Poland [Czapliński, Ładogórski 1998].

At the turn of $16^{\text {th }}$ century, ore-based settlements were established on the Omulew. At the beginning of the $17^{\text {th }}$ century, people who inhabited the forest began to settle here permanently, cleared pieces of the forest in order to gain land for the cultivation of fodder plants and vegetables. However, the soil was rather barren and sandy here. Therefore, the forest still remained the main source of food and income [Niedziałkowska 1988]. Until the mid-seventeenth century, the settlement progressed deeper into the forest at a very slow pace. No compact villages were erected here, and forestry-water based economy still prevailed almost exclusively. In connection with the above, the area of Puszcza Zielona [Zielona Forest], was significantly lagging behind in economic and agricultural development, compared to other lands of Mazovia.

Towards the end of the $17^{\text {th }}$ century, the influx of people to the forest was on the increase. Apart from villages founded by starosts (intended to benefit from agricultural easement payments) and occasionally by private persons, the majority of settlements were formed spontaneously. The estates plans provide information on which layouts were established in accordance with the typology of rural settlement, and which arose spontaneously following settlement laws that resulted from the nature of the area. An established, or regular, village was marked with a predetermined outline, the influence of conscious and creative human thought is visible. On the other hand, a spontaneous or unprompted village was commenced with one or more homesteads, randomly scattered, and developed in an unplanned manner.

Since the mid-eighteenth century, following the introduction of reforms, a clear modification to the layouts of emerging habitats could be observed. Villages began to be built along one or three main roads descending to the center, where a chapel or a couple of beautifully adorned crosses were erected. The layout of residential buildings was a characteristic feature of the Kurpie villages. The cottages were lined up along the main roads, all facing the road with their gable walls. The streets facing the fields and forests were closed at night with wooden gates, thereby isolating the entire village from wild animals [Chętnik 1915]. 
In fact, it can be stated that the settlement process in Puszcza Zielona [Zielona Forest] was concluded during the times of free Poland. This is because in the $19^{\text {th }}$ century only a few poor villages inhabited mainly by cottage industry workers were established here. Following the fall of the Polish-Lithuanian Commonwealth in 1795, after the Third Partition of Poland, the Ostrołęka poviat together with the Kurpie region fell under Prussian rule, thus becoming part of the Płock department, New East Prussia.

As a result of the Congress of Vienna, 1815 which followed Napoleon's defeat, the Kingdom of Poland, also called the Congress Kingdom or the Congress Poland was formed. It remained part of the Russian partition. The kingdom was divided into eight provinces. The Ostrołeka poviat remained administratively connected with Płock; during the Prussian rule the region was part of the Płock Department, now it became part of the Płock Province [Niedziałkowska 1988].

In 1831, the fall of the November Uprising became a fact. It was a very difficult period in Kurpie people's life. Most of their crops and settlements were destroyed yet again, while the tsarist governor introduced very strict rules in many areas of life.

In the mid-nineteenth century, land regulation was performed in some of the villages, namely in the area of Puszcza Zielona [Zielona Forest].

The years from 1846 to 1856 were a period of abject poverty for the Kurpie families. It was caused by administrative restrictions and a wave of disasters, namely torrential rains and scorching heat, both of which exacerbated the deficiency of livestock and food. By an order of 1853, budnicy [whose job was to deal with wood processing and its products], jednosielcy [budnicy, who kept livestock] and katnicy [craftsmen who did not own property or cottages] were removed from the forest, with the aim of separating forest property that belonged to the government from peasant farms. For some Puszcza inhabitants, this meant a change in the source of income, while the number of landless inhabitants, cottage industry workers, and loose people with no job, increased.

During the January Uprising of 1863 and 1864, the inhabitants of Puszcza Zielona [Zielona Forest] participated in numerous skirmishes against the armed Russian army in this area. In the Manifesto of January 22 ${ }^{\text {nd }}, 1863$, The National Government constituted upon the outbreak of the Uprising announced the enfranchisement of all villagers. After the fall of the Uprising, persecutions, arrests and deportations to Siberia took place, but neither the Tsar himself, nor the administrative authorities of the Kingdom of Poland dared to overturn the enfranchisement provisions.

Land consolidation should be seen as the factor that significantly influenced the nature of changes in the Kurpie agriculture over the period from granting property to 1914. As a result of the consolidation, the layout of village buildings underwent changes. Farmers erected their farms on new land, in colonies. In this period, emergence of patriarchal-family farms was characteristic. Moreover, prevalence of medium-sized farms with a decreasing number of large ones was noted, with field patch work layout, fragmentation of farms focused mainly on farmers' own use and the excess of labor force. 
Most of the Kurpie villages were burned down as a result of the 1914-1918 hostilities. On November $11^{\text {th }}, 1918$, when the Republic of Poland regained its independence, the situation in the Kurpie region was disastrous. In 1920, the withdrawing Soviet troops were retreating also through Puszcza Zielona [Zielona Forest], which caused further destruction to this area. In the interwar period, the number of small-sized farms increased, the number of large ones decreased, whereas the number of medium-sized farms remained nearly constant. The second land consolidation provided an important factor to influence the development of agriculture. It was performed after 1926, based on the land reform of 1923 and the consolidation reform. In the years from 1918 to 1939, the condition of agriculture in the Kurpie region slowly improved, but little chance was there for farming development at a scale similar to that in other territories of the Republic of Poland.

To sum up, the identification and, simultaneously, the distinctiveness of the Kurpie region was influenced by factors that resulted from the physiographic conditions of the area. These included, above all, dense afforestation, especially in the initial period of settlement, as well as barren lands and the peripheral nature of the studied area. All these factors made it possible for the settlement systems to emerge and function to this day, as well as to develop regional distinctiveness, expressed in broadly understood heritage of material and spiritual culture.

\section{The Kurpie region 2004 - characteristics of settlement landscape}

The region included in the territorial scope of the present work covers an area of approximately $1400 \mathrm{sq}$. km., $57 \%$ of which is arable land, whereas $35 \%$ is forest land. This part of the poviat is inhabited by approx. 56 thousand people. The population density equals approximately 39 people per a sq. $\mathrm{km}$. The communes covered by the present work are located in the area known as Zielone Płuca Polski [Green Lungs of Poland], characterized by high value of the natural environment, uncontaminated by burdensome industry. The natural landscape of the studied area is characterized by alternating strips of land along north-west towards south-east axis. This arrangement is typical for the Kurpie plain, which is dominated by forest complexes that overgrow dunes, rivers: Szkwa, Rozoga, Piasecznica and Omulew, flat wide valleys of these rivers with complexes of grasslands. Arable fields with a varied share of trees and shrubs, with endorheic depressions complement the landscape.

The nature of spatial settlement layouts is closely related to separated units and zones. In the area of the seven surveyed communes, three types of spatial settlement patterns can be distinguished:

1. Dispersed settlement of a linear and surface character. These villages are usually inhabited by no more than 100 inhabitants.

2. Clustered settlements of a street-based or row-based nature and strip layout of arable fields of land. This type of settlement occurs mainly at the border of the edge zone of the valleys and forest complexes. 
3. Compact settlement with various layers of building development and forking road system in letter $\mathrm{V}$ shape (widlica) or a spatial arrangement type of buildings located along several roads (wielodrożnica).

Dwellings (zabudowa siedliskowa) is the dominant form of development in the analyzed communes, as it occurs in all settlement units. Its plan and layout are closely related to cultural conditions. The settlement genotype of the village proves its autonomous emergence, the shape of dwellings was mainly influenced by the habits of people living there, as well as by the rules for shaping the place of habitation passed down from generation to generation.

Nowadays, typical residential building development emerges in all villages, most often in those with a large number of inhabitants and in the vicinity of cities. Such development provides a supplement to the traditional settlement tissue. The majority of the buildings erected in the post-war period refer to the folk architecture of Kurpie region only to a very small extent.

The continuation of traditional forms of development does not mean imitation, but should incorporate interpretation, with reference to the present day. Not all objects have to refer to the Kurpie culture, but new forms should maintain the right proportions and be harmoniously integrated into the landscape. The lack of standards with which to define development constitutes a major problem. This is especially true in the case of areas of value in terms of nature and landscape, with a preserved cultural landscape, both with attention to shapes and construction technology.

\section{The Kurpie region - dominant changes to landscape under the influence of socio-economic factors in the 45 post-war years}

Following World War II, administrative division of Poland underwent five major changes: the functioning of communes (1944-1954), the existence of communes (1955-1972), the return to communes in 1973, liquidation of poviats and establishing a two-tier division of the country in 1975, return to poviats and reduction to the number of voivodeships in 1999 [Wiśniewska 1999].

The Kurpie region is characteristic owing to the presence of a large number of localities with a low population density. This proportion proves the considerable settlement dispersion. The structure of the settlement network resulted from changes in the population of the Kurpie region. These changes may easily be noticed after analyzing the number of people who dwell in individual villages and the number of permanently inhabited residential buildings.

In the 45-year post-war period, significant changes to the rural settlement network of the Kurpie region took place. The number of villages with 500 to 999 inhabitants decreased, while the number of the smallest villages with less than 100 inhabitants increased. In terms of the number of permanently inhabited buildings, the largest number of such developments was observed in villages with 20 to 49 buildings. This situation remained rather stable over the analyzed period. This fixedness is the result of the decline in the number of rural populations 
with the almost unchanged number of families. It is also influenced by contemporary tendencies of newly established families to live independently.

Significant changes in the population distribution occurred in the analyzed period. Villages which location is peripheral to Ostrołęka and main communication routes that connect Warsaw with Ostrołęka, as well as the transit road towards Mazury [Masuria] are experiencing depopulation. Villages with scattered building development are at a significant advantage in this area. The concentration of population occurs in commune villages, as well as in the immediate vicinity of Ostrołeka. The popularity of these places is related to the availability of work outside agriculture, and thus a chance to maintain or improve the material conditions of life. Unfavorable natural conditions for agriculture which fails to be highly productive in the study area, as well as the lack of other functions provide the main factors behind the depopulation of the villages in Puszcza Zielona [Zielona Forest], discussed above.

The Kurpie region is one of the areas marked with low productivity of agriculture. This is evidenced by the lowest nationwide indices of mechanization for individual farming, professional training of farmers and very low agriculture production effects. This includes, in particular, the low value of agricultural production per 1 ha of arable area. Despite the low yield, agriculture dominates as a leading function in the rural areas of the Kurpie region. The reason for this lies in the lack of multi-functionality of the area, as other sectors of economy are even less developed here.

\section{The Kurpie region - dominant changes to landscape under the influence of socio-economic factors in political transformation period}

In 1989 in Poland, political and social transformations were initiated, leading to reconstruction of the existing economic structures. The transition from a command-and-distribution system of economy management to a market economy was commenced. These transformations also marked the beginning of the process of changes in agriculture structure. Consequently, modifications to the structure of settlement in rural areas followed, which process continues to the present day.

Compared to the rest of the country, the percentage structure of analogous area-related groups of farms is much more favorable in the Kurpie region. Generally, in Poland, farms from 1 to 5 ha occupy almost $59 \%$ of the area of all arable land. In the Kurpie region, however, the share of such farms slightly exceeds $5 \%$. The share of farms with the area from 5 to 10 ha remains at a similar level to that in the rest of the country. The share of large farms within the range of 10 to 15 ha definitely exceeds the share of such farms in the country as a whole $(9 \%)$ and amounts to over 30\% in the Kurpie region. Likewise, the structure of the studied area involves a much higher share (namely 40\%) of the largest farms with an area of over 15 ha, whereas the share of such farms in the country's structure stands at $10 \%$.

Research on the population, and thus settlement structure in the studied area, was conducted in the period of 15 years since political system transformation. The results differed 
from those obtained in the period of 45 post-war years. An increase in population in all surveyed communes was noted. In most communes, it amounted to around $10 \%$. The research showed that the age structure declined in the analyzed period. The percentage of people at post-productive age has increased, whereas the percentage of people at productive age has significantly decreased, especially in the 20-29 age group. The ratio of women to men in this range is also unfavorable. It is caused by the fact that young people, especially women, leave their family farms in search of easier jobs in the city.

\section{Summary}

The Kurpie region is specific, with its predominant agricultural function. Despite the poor and rather barren soils, settlements related solely to farming developed here. The restructuring of agriculture and rural settlement caused by the systemic transformation and civilization development applies to the studied area as well. Factors, such as population aging and relocation of the young to cities, uneconomical structure of farms, as well as non-adapted base off arm building indicate that agricultural production can be rational only in areas where it will be possible to increase farm ranges on relatively good soils.

The ongoing restructuring of agriculture leads to modification to spatial layout of the buildings and landscape of the Kurpie village towards ecological family farms and recreational buildings. Nowadays, the landscape of Kurpie villages is undergoing a transformation towards the reconstruction of the natural landscape, whereas the area is gradually gaining in cultural and natural potential for the development of tourism.

\section{References}

Chętnik A., 1913, Puszcza Kurpiowska, Księgarnia Polska, Warszawa.

Chętnik A.,1915, Chata kurpiowska. Opracowana podtug materiałów zebranych na miejscu, z 207 fotogr., planami i rysunkami wykonanymi przez Autora, Ksiegarnia Gebethnera i Wolffa, Warszawa.

Czapliński W., Ładogórski T., 1998, Atlas Historyczny Polski, PPWK Oddział Wrocław.

Jałowiecki B., 1989, Przestrzeń znaczaca [in:] J. Wódz (ed.), Przestrzeń znacząca, Studia Socjologiczne, Śląski Instytut Naukowy, Katowice.

Jaworowski J., Jankowski S., 1996, Czynniki produkcji w rolnictwie woj. ostrołęckiego w latach 1975-1994, Zeszyty Naukowe OTN, X, Ostrołęckie Towarzystwo Naukowe, Ostrołęka.

Mikulska J., 1998, Ostrołęka i Kurpie w literaturze pięknej, Wojewódzka Biblioteka Publiczna im. Wiktora Gomulickiego w Ostrołęce, Ostrołęka.

Niedziałkowska Z., 1988, Kurpie. Bory Ostrołęckie, Ludowa Spółdzielnia Wydawnicza, Warszawa. 
Pajka S., 1996, Pisarze i badacze Kurpiowszczyzny, Zeszyty Naukowe X, Ostrołęckie Towarzystwo Naukowe, Ostrołęka.

Piaścik F., 1939, Osadnictwo w Puszczy Kurpiowskiej, Wydawnictwo Zakładu Architektury Polskiej i Historii Sztuki Politechniki Warszawskiej, Warszawa.

Starzyk A., 2004, Przekształcenia otwartego krajobrazu osadniczego na Kurpiowszczyźnie na przykładzie wybranych gmin (doktorat), Wydział Architektury, Politechnika Warszawska, Warszawa.

Wiśniewska M., 1999, Osadnictwo wiejskie, Oficyna Wydawnicza Politechniki Warszawskiej, Warszawa. 


\section{Kurpiowszczyzna \\ Przekształcenia krajobrazu osadniczego do czasu przystąpienia Polski do Unii Europejskiej}

\section{STRESZCZENIE}

Kurpiowszczyzna to jeden $\mathrm{z}$ ciekawszych regionów etnograficznych, z ośrodkiem oryginalnej, świetnie zachowanej i pieczołowicie kultywowanej kultury ludowej Kurpiów. Obraz wsi kurpiowskiej jest wynikiem wielowiekowych działań człowieka. Na przestrzeni stuleci następowały przekształcenia krajobrazu, oparte na przystosowywaniu środowiska przyrodniczego do uprawy ziemi i stopniowym zakładaniu siedzib ludzkich, które dały obraz współczesny. Tradycyjna kultura ludowa kurpiowskiej grupy etnograficznej oraz wysoka wartość środowiska przyrodniczego były inspiracją do podjęcia badań z zakresu transformacji otwartego krajobrazu osadniczego regionu kurpiowskiego. Celem pracy było zbadanie procesów decydujacych o przekształceniach krajobrazu naturalnego i kulturowego Kurpiowszczyzny.

Zakres terytorialny pracy obejmuje obszar Kurpiowszczyzny położony między Omulwią i Szkwa, który w XV w. znalazł się w powiecie ostrołęckim i w nim pozostał. Zakres czasowy badania obejmuje okres od pierwszych wzmianek o zasiedlaniu obszaru do czasu przystapienia Polski do Unii Europejskiej.

Przyjęte zostały następujące metody badawcze: analizy bibliograficznej i piśmiennictwa dotyczącego tematu pracy, analizy historycznej obejmującej rozwój osadnictwa na badanym terenie, analizy kartograficznej porównawczej w zakresie osadnictwa i przekształcania krajobrazu, analizy statystycznej w zakresie infrastruktury społecznej i technicznej. W pracy posługiwano się także inwentaryzacją krajobrazową i urbanistyczno-ruralistyczna.

Struktura cyklu, zawarta w siedmiu artykułach, obejmuje zagadnienia związane z kształtowaniem i rozwojem osadnictwa na obszarze Kurpiowszczyzny: 1) Kurpiowszczyzna w badaniach naukowych, 2) Kurpiowszczyzna w kulturze ludowej, 3) Kurpiowszczyzna - zarys kształtowania funkcji osadniczo-rolniczych i krajobrazu, 4) Kurpiowszczyzna - charakterystyka krajobrazu osadniczego, 5) Kurpiowszczyzna - dominujące zmiany w krajobrazie pod wpływem czynników społeczno-ekonomicznych w okresie 45-lecia powojennego, 6) Kurpiowszczyzna - dominujące zmiany w krajobrazie pod wpływem czynników społeczno-ekonomicznych w okresie transformacji ustrojowej. Cykl zamyka artykuł dotyczący współczesności: 7) Kurpiowszczyzna - 18 lat od wstapienia Polski do Unii Europejskiej (publikacja w 2022).

Słowa kluczowe: Kurpie, architektura, krajobraz osadniczy, krajobraz przyrodniczy, krajobraz kulturowy

\footnotetext{
Agnieszka Starzyk, PhD, Arch, Assoc Prof-academic teacher and practicing architect; contact to the author: Warsaw University of Life Sciences, Institute of Civil Engineering, Department of Revitalization and Architecture,

e-mail:agnieszka@starzyk.org.pl

Agnieszka Starzyk, dr hab. inż. architekt - nauczycielka akademicka i praktykujq̨ca architektka; kontakt do autorki: Szkoła Główna Gospodarstwa Wiejskiego w Warszawie, Instytut Inżynierii Lądowej, Katedra Rewitalizacji i Architektury,

e-mail:agnieszka@starzyk.org.pl
} 